Ph.D. candidate,

Faculty of Law, Masaryk University, Brno,

Czech Republic

UDK: 543.533 .3

347.78

Рад примљен: 01.10.2019.

Рад прихваћен: 06.05.2020.

\title{
PARODY AND INTELLECTUAL PROPERTY LAW IN THE CONTEXT OF EMERGING FASHION LAW ${ }^{* *}$
}

\begin{abstract}
This article deals with the relationship between parody and intellectual property law. First, the author presents the concept of parody in European law. In this context, the CJEU judgment delivered in the case Deckmyn $v$. Vandersteen is extensively analyzed. In addition to discussing parody within the framework of copyright and trademark law, the author presents several cases from the emerging area of fashion law. As the CJEU has not ruled on any case concerning fashion law, the author mainly focuses on the United States case law. Most cases related to fashion law usually end in confidential agreements and out of court settlement. Yet, several cases were decided in national court proceedings. All these cases illustrate how parody is used ineverydaylife in the fashion world.
\end{abstract}

Keywords: European Law, parody, Intellectual Property Law, fashion law, Louis Vuitton, Chanel, Hermes.

\section{Introduction}

In intellectual property law, the boundary between parody, inspiration and imitation is fragile. What is legally considered to be parody? Does legal framework provide any definition of parody? Is parody legally acceptable, or does it infringe someone's rights? What are the examples of parody in intellectual property rights? This article focuses on and discusses these questions. The author also presents relevant case law demonstrating the implementation of theory in practise.

*sarka.silhankova@gmail.com

** Рад је био изложен у виду усменог саопштења на Међународној научној конференцији „Право и мултидисциплинарност“ одржаној на Правном факултету Универзитета у Нишу 12. и 13. априла 2019. 


\section{The concept of parody in the European Union \\ Copyright Law - case Deckmyn v. Vandersteen ${ }^{1}$}

\subsection{Background of the case}

The case Deckmyn $v$. Vandersteen is the first judgment concerning the concept of parody which was delivered by the Court of Justice of the European Union (hereinafter: CJEU). The judgment is undoubtedly ground-breaking. Although it can be dated back to 2014, the decision is still considered to be the only decision which explains and gives comprehensive answers to the issue of parody in EU intellectual property law.

The origin of the case lies in a calendar for the year 2011 which was publicly distributed at a public event in the City of Ghent (Belgium). The cover picture of the calendar is a reproduction of a well-known comic book. The calendar conveys a message which entails political ideology. The applicants were the heirs of Mr. Vandersteen, the author of the famous comic book Suske en Wiske ${ }^{2}$, while the defendant was Mr. Deckmyn, a member of a Flamish nationalist political party Vlaams Belang. Mr. Deckym distributed the calendar at the event organized at a reception in the City of Ghent, and the copyrighted work was later published on the website of Vlaams Belang. The disputed cover of the calendar depicted the City Mayor dressed in a white tunic. The applicants argued that the defendant simply copied the old cover of Suske en Wiske comic book.

1 Case C-201/13 Deckmyn v. Vandersteen and Judgment of the Court (Grand Chamber), 3 September 2014. The summary and analysis of this case is based on the Opinionof the Advocate General delivered on 22 May 2014, http://curia.europa.eu/juris/document/document.jsf;jsessionid=368150D79784A375E1812AB0900AE8A9?text $=\&$ docid=157281 \&pageIndex=0\&doclan $\mathrm{g}=\mathrm{EN} \&$ mode $=$ lst $\&$ dir $=\&$ occ $=$ first $\&$ part $=1 \&$ cid $=9417447$ \# Footnote*

2 The comic book Suske en Wiske was created in 1945 and it is particularly well-known in the Dutch-speaking areas; in French, it is known as Bob and Bobette; in English, it is known as Spike and Suzy. 
Picture 1: The Calendar cover page

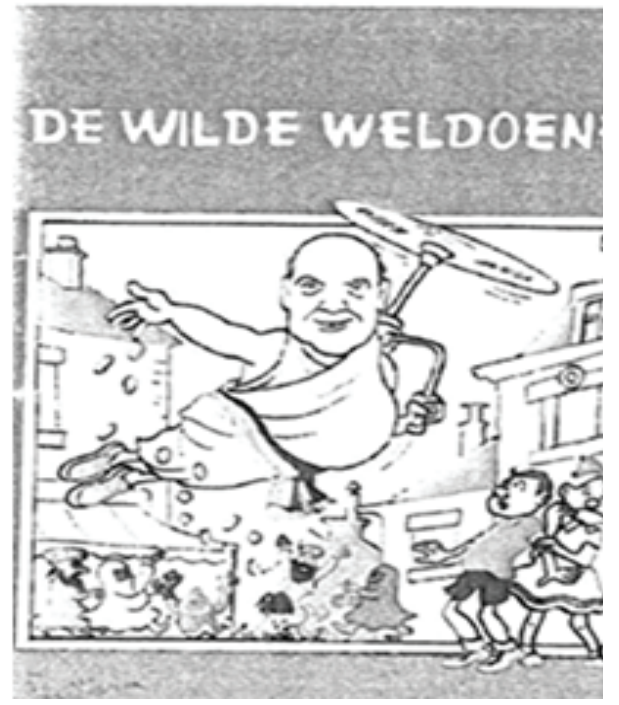

Picture 2: Suske en Wiske comic book

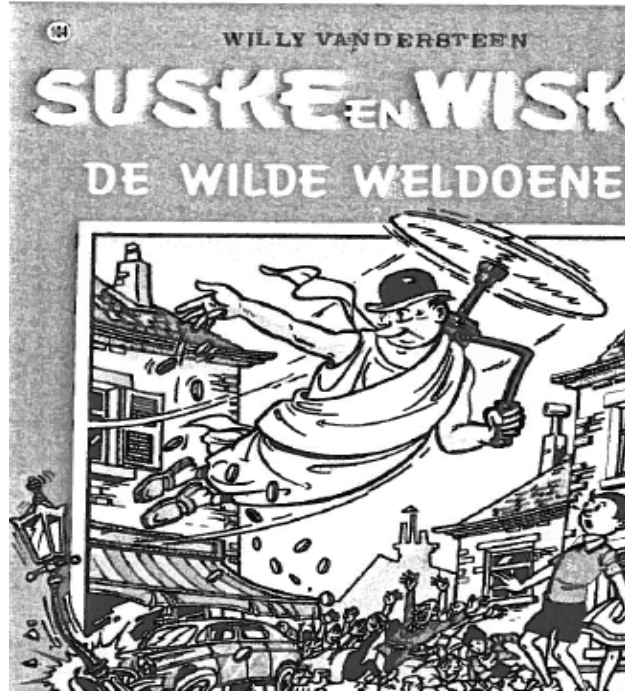

Source: Info Curia Case-law: Case C201/13 Deckmyn vVandersteen (2014), CJEU³

\subsection{The case in front of the national courts in Belgium}

In 2011, the applicants filed a lawsuit against the defendant, claiming the infringement of their copyright for Suske en Wiske comic book. It is important to mention that the original work depicts an unknown man (one of the comic book characters) dressed in a white tunic, while the reproduction in the calendar depicts a real politician. Moreover, in the reproduction, the people in the street were depicted as people of colour, wearing burkas and picking up the coins thrown by the politician. According to the applicants, the work has a strong political subtext and conveys a message that they do not wish to be associated with.

The competent national court (Court of First Instance, Brussels) held that the distribution of the copyrighted work without permission of the applicants constituted an infringement of their copyright and rendered the judgment in favour of the applicants. Consequently, the defendant was obliged to cease using the disputed drawing on the calendar and was imposed a fine in the amount of 5.000 EUR for each day of unauthorized use of the copyright (to the maximum amount of 500.000 EUR).

3 CJEU: Info Curia Case-law: Case C201/13 Deckmyn and Vrijheidsfonds VZW vVandersteen and Others, Opinion of Advocate General, delivered on 22 May 2014; http://curia.europa.eu/ juris/document/document.jsf?text $=\&$ docid $=152656 \&$ pageIndex $=0 \&$ doclang $=C S \&$ mode $=l s$ t\&dir $=\&$ occ $=$ first $\&$ part $=1 \&$ cid $=9420552$ 
The defendant expectedly appealed. The appeal was, inter alia, based on the ground of parody exception. Mr. Deckmyn asserted that his drawing was a political cartoon which fell within the scope of parody and, as such, it could not constitute a copyright infringement. On the other hand, Mr. Vandersteen's heirs claimed that the cover drawing of the calendar was very similar, or nearly the same as the original (in way of typing, colour, the figure in tunic, etc.). Moreover, they kept asserting that the overall impression of the reproduction was discriminatory (concerning people of colour, people wearing burkas) and represented political propaganda, which they did not want to be associated with. ${ }^{4}$ The applicants persisted on the argument that their rights had been infringed.

\subsection{Legal context}

To properly address the legal issue whether Suske en Wiske comic book was parodied or whether the copyright was infringed, the reader should be introduced to the legal framework.

First, the European Union Directive 2001/295 states:

"The proposed harmonisation will help to implement the four freedoms of the internal market and relates to compliance with the fundamental principles of law and especially of property, including intellectual property, and freedom of expression and the public interest."

Recital 31 in the Preamble to that Directive reads:

"A fair balance of rights and interests between the different categories of rightholders, as well as between the different categories of rightholders and users of protected subject-matter must be safeguarded."

Article 5 of the Directive, titled "Exceptions and Limitations", provides in paragraph 3:

"Member States may provide for exceptions or limitations to the rights provided for in Articles 2 and 3 (entitled respectively "Reproduction right" and "Right of communication to the public of works and right of making available to the public other subject-matter") in the following cases: (...)

(k) use for the purpose of caricature, parody or pastiche; (...)"

On this matter, Belgian law envisages as follows:

Article 22(1) of the Law of 30 June 1994 on copyright and related rights

4 At that time, Vlaams Belang was a political party of the far right.

5 Directive 2001/29/EC of the European Parliament and of the Council of 22 May 2001 on the harmonisation of certain aspects of copyright and related rights in the information society. 
"Once a work has been lawfully published, its author may not prohibit: (...)

6. caricature, parody and pastiche, observing fair practice; (...)"

To sum up, European law says that Member States "may provide for exceptions or limitations", which means that the possible list is optional only. Each Member State can decide whether the list is implemented into their national laws or not. Belgium availed the option and implemented expectations and/orlimitation into the national law. According to Belgium law, an author cannot prohibit parody if used fairly. However, the law does not provide any guidelines about thedefinition of parody and its fair use. Hence, in order to address this issue, the Court of Appeal in Brussels stayed the proceedings and referred preliminary questions to the CJEU for a preliminary ruling.

\subsection{The case in front of the CJEU}

In 2013, the national court in Belgium raised the following preliminary questions:

- Is the concept of "parody" an autonomous concept in EU law?

- If so, must a parody satisfy or conform to the specific characteristics, such as: displaying an original character, seeking to be humorous or to mock, mentioning the source of the parodied work?

\section{Definition and characteristics of parody}

Although the Directive talks about parody, it does not provide any definition or reference to national law. According to the European law principles, if there is no reference to national law, the concept should be interpreted independently and uniformly, having regard to the context of the provision and the objective of the relevant legislation. In other words, parody is an autonomous concept.

The CJEU stated that parody is an imitation, created for the purposes of mockeryof a work protected by the Directive, without there being any possibility of imitation causing confusion with the original work.In other words, parody:

- imitates,

- has a humorous or mockery subtext,

- does not cause confusion with the original work,

- is used fairly. ${ }^{6}$

6 CJEU Case C-201/13 Deckmyn v. Vandersteen and Judgment of the Court (Grand Chamber), 3 September 2014. 
Parody is a copy of the original work, but it is also required to be an independentoriginal work itself, not a mere copy of the original. Parodies which fulfil these criteria manifest the freedom of speech. Pursuant to Article 10 (para. 2) of the European Convention on Human Rights, ${ }^{7}$ freedom of expression must be respected even though information or ideas offend, shock or disturb, even if freedom of expression is not unlimited in a democratic society.

At the end of this section, it is important to mention that parody exception is to be applied only in some special cases which are not considered to conflict with a normal exploitation of the work or other subject matter, and do not unreasonably prejudice the legitimate interests of the copyright holder.

The determination of whether the conditions remain satisfied is a matter which must be resolved by national court. In the author's opinion, the conditions whether parody is in accordance with accepted principles of morality should be observed as well.

\section{- Trademark law}

So far, the CJEU has not delivered any judgment concerning the concept of parody in trademark law. However, the legal framework may provide a solution in this matter.

\section{Recital 21 of Regulation (EU) 2017/1001 ${ }^{8}$ states:}

"Use of a trade mark by third parties to draw the consumer's attention to the resale of genuine goods that were originally sold by or with the consent of the proprietor of the EU trade mark in the Union should be considered as being fair as long as it is at the same time in accordance with honest practices in industrial and commercial matters. Use of a trade mark by third parties for the purpose of artistic expression should be considered as being fair as long as it is at the same time in accordance with honest practices in industrial and commercial matters. Furthermore, this Regulation should be applied in a way that ensures full respect for fundamental rights and freedoms, and in particular the freedom of expression."

In the author's opinion, the conditions under which one's work is considered to be a parody are the same as the conditions mentioned above in the section about copyright law. In both cases, freedom of expression should be respected but it cannot be absolute. As already noted, the honest and fair use of trademark is the only key which can answer the question at issue. Trademark, just as other

7 The EU Member States observe the ECHR although it is not the legal source of the European Union.

8 Regulation (EU) 2017/1001 of the European Parliament and of the Council of 14 June 2017 on the European Union Trademark 
intellectual property rights, may be subject to parody but parody exception should not be applied to every modification of the copyrighted work.

\section{Parody and Emerging Fashion Law}

Fashion designers and fashion houses usually choose to legally protect their items bytrademark and design. High fashion designers choose other forms of legal protection, but their fashion items mostly profit fromcopyright. So far, the CJEU has not rendered any decision concerning fashion law and parody, but several decisions on this issue can be found in case law of national courts in the European Union and mainly in the United States. Louis Vuitton is the most famous fashion brand, well-known for extensive legal protection of its intellectual property rights. They usually choose to fight their trademark infringement cases in court, while other brands often resort to settling disputes out of court.

\subsection{Louis Vuitton}

The author has already written an article about Louis Vuitton ${ }^{9}$ and its extensive legal action over unauthorised uses of intellectual property rights. Therefore, in this article, the author presents only a brief summary of relevant cases.

In this context, the case Nadia Plesner v. Louis Vuitton ${ }^{10}$ is of particular relevance. A young artist Nadia Plesner made the work "Simple living", which inter alia showed an African child holding a handbag and a Chihuahua dog dressed in pink. The handbag was the Audra Louis Vuitton bag, whose graphic symbols are protected under the Community design. ${ }^{11}$ Moreover, Plesner's work was linked to the political situation in Darfur (Sudan). When comparing the two cases presented in this paper, Louis Vuitton had the same arguments as Mr. Vandersteen's heirs and did not wish to be associated with the alternation.

9 Šilhánková, Šárka (2019). Louis Vuitton as a Bully Brand. In: European Legal Studies and Research. International Conference of PhD Students in Law. Timisoara: Faculty of West University of Timisoara, 2019, pp. 372-377.

10 Court of the Hague Judgment, dated 4 May 2011, case number 389526/KG ZA 11-294 [online]. [cit. 28. 8. 19].

11 Registered Community Design number 000084223-0001. EUIPO European Union IntellectualProperty Office. (C) EUIPO 1995-2019. [cit. 28. 8. 19]. 
Picture 3: Simple living by Nadia Plesner (2010)

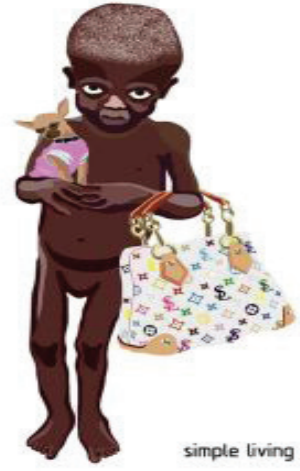

Source: Nadia Plesner website: Simple Living \& Darfurnica (undated) ${ }^{12}$
The applicant Louis Vuitton filed an action against the defendant Nadia Plesner. The case was complicated as there were two proceedings in total. Louis Vuitton invoked Article 1 of the Protocol of the ECHR (the protection of property, including design rights), while Nadia Plesner invoked Article 10 of the ECHR (freedom of expression). The Court of the Hague (the Netherlands) had to find a fair balance between these two fundamental rights. The fair balance was found in 2011, when the Court of the Hague ultimately ruled in favour of Nadia Plesner. The court ruled that artistic

expression should overweigh the interest of peaceful enjoyment of property. Thus, a young artist won the courtroom battle against the big and powerful fashion house.

In the author's opinion, the Dutch court rendered such a decision because Plesner did not use the Louis Vuitton intellectual property right as an eye-catcher to make money (as compared to Mr. Deckmyn). Plesner just wanted to raise the public awareness about the political situation and the warfares in Darfur, given that the western countries did not provide much information on this matter to their general public. On the other hand, media widely informed the public about the life of celebrities (holding dogs in public events, wearing luxury handbags, etc.). Thus, Plesner created a link between these two worlds in order to draw attention to issues that really mattered in her opinion.

Other famous cases are My Other Bag v. Louis Vuitton ${ }^{13}$ and Haute Diggity Dog v. Louis Vuitton. ${ }^{14}$ In both cases, the action was taken in the United States and the courts found that the artists did not infringe Louis Vuitton's intellectual property rights as they successfully met the criteria for parody exception.2.1.

12 Nadia Plesner website: Simple Living \& Darfurnica; http://www.nadiaplesner.com/ simple-living--darfurnica1

13 Judgment of the United States Court of Appeals, Second Circuit, dated 22 December 2016. Louis Vuitton Malletier, S.A., Plaintiff-Appellant, v. My Other Bag, Inc., Defendant-Appellee, case number 16-241-cv [online]. [cit. 28. 8. 19].

14 Judgment of the United States Court ofAppeals for the Fourth Circuit, dated 2007. Louis Vuitton Malletier S.A. v. Haute Diggity Dog, LLC, case number 507 F.3d 252 [online]. [cit. 28. 8. 19]. 


\subsection{Chanel}

Louis Vuitton has not been the only brand which had to deal with unauthorized use of its intellectual property. Chanel is known for its CC monogram. Yet, the brand "What about Yves" used the iconic monogram together with the image of Ghostbusters. T-shirts were sold to public. Although Chanel filed a lawsuit, the case was ultimately settled out of court in 2015. The conditions of the out-ofcourt settlement are confidential. ${ }^{15}$

Picture 4: T-shirts with the dispited Chanel (CC) monogram

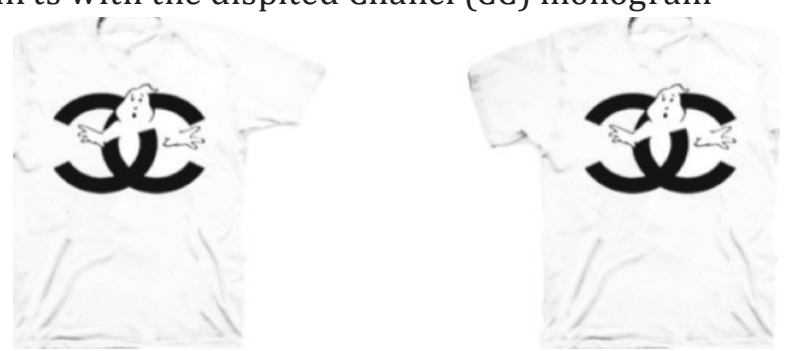

Source: TFL: Chanel Settled its lawsuit over "Parody" Tee, Diesel to Sue? (April 13, 2015)

\subsection{Hermes}

Like Louis Vuitton (in the case My OtherBag), Hermes had to deal with a similar trademark infringement lawsuit. In both cases, their intellectual property rights (iconic trademark-protected bags) were used as a picture printed on canvas bags. In Hermes case, similarly to Chanel, the parties settled out of court. ${ }^{17}$

Picture 5: Hermes bag v Thursday Friday bag

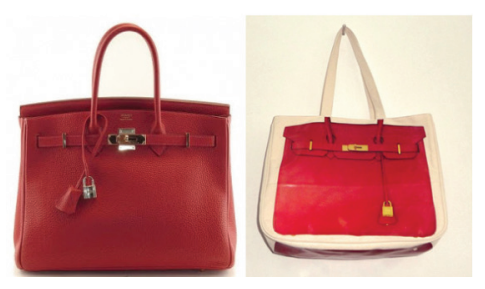

Source: TFL: Hermes v Thursay Friday (August 1. 2001) ${ }^{18}$

15 The Fashion Law [online]. Chanel Settled its Lawsuit Over „Parody“ Tee, Diesl to Sue? (April 13, 2015)

16 TFL: https://www.thefashionlaw.com/chanel-settled-its-lawsuit-over-parody-teediesel-to-sue/

17 The Fashion Law [online]. Hermes v. Thursday Friday (August 1. 2001),TFL LLC, [cit. 28. 8. 19]

18 TFL: https://www.thefashionlaw.com/hermes-v-thursday-friday/ 


\section{Conclusion}

In the introduction, the author has raised several questions related to the boundary between parody, inspiration and imitation in the context of intellectual property rights. The article has focused on the analysis of the concept of parody and how parody and intellectual property law can interact. The author has presented the available legal framework and relevant legal cases on this subject matter.

According to the CJEU case law, parody imitates the original work on a humorous or mockery subtext. Parody does not cause confusion with the original work and must be used fairly. Given that parody is a copy of the original work, it should not be considered an original work. However, atthe same time, the copied original creates a secondary original (parody).

European legal framework concerning copyright provides exceptions and limitations for thereproduction right, the right of communication of works to the public, and the right of making other intellectual property assets available to the public in case they are used for the purpose of parody. As the provided list is only optional, the EU Member State are fully entitled to decide whether they will implement the EU legislative framework into the national law. When it comes to case law, the national courts have the authority to decide whether the derivative work, which is claimed to represent a parody, has truly met the aforesaid criteria and, possibly, grant the parody exception. According to the European Union standards, the freedom of speech should be observed in the proceeding. On the other hand, it also means that the freedom of speech cannot be an absolute right even in democratic countries.

The author has also analysed the EU legal framework on trademark law. In the author's opinion, trademark law should apply the same criteria on parody as copyright law.

In the second part of the article, the author has presented how parody is used in the emerging area of fashion law. This issue has been illustrated by a number of relevant legal cases involving well-known fashion brands, such as Louis Vuitton, Chanel and Hermes. While Louis Vuitton is renowned for extensive legal protection of its intellectual property in court, the author also presents the results of out-of-court settlements agreed by Chanel and Hermes when their intellectual property rights were subject to unauthorized use. 


\section{References}

Judicial decisions

Judgment of the Court of the Hague, dated 4 May 2011, Nadia Plesner Joensen, claimant, v. Louis Vuitton MalletierSA, case number 389526/KG ZA 11-294 [online]. [cit. 5. 5. 19]. Available at: http://www.nadiaplesner.com/upl/website/ simple-living--darfurnica1/VerdictEnglish.pdf

Judgment of the Court of Justice of the European Union (Grand Chamber), 3 September 2014, in Case C-201/13 Deckmyn v. Vandersteen. Available at: http:// curia.europa.eu/juris/document/document.jsf;jsessionid=368150D79784A37 5E1812AB0900AE8A9?text $=\&$ docid $=157281 \&$ pageIndex $=0 \&$ doclang $=E N \& m o$ de $=$ lst \&dir $=\&$ occ $=$ first $\&$ part $=1 \&$ cid $=9417447 \#$ Footnote*

Judgment of the United States Court of Appeals, Second Circuit, dated 22 December 2016. Louis Vuitton Malletier, S.A., Plaintiff-Appellant, v. My Other Bag, Inc., Defendant-Appellee, case number 16-241-cv [online]. [cit. 28. 8. 19]. Available at: https://caselaw.findlaw.com/us-2nd-circuit/1762991.html

Judgment of the United States Court of Appeals for the Fourth Circuit, dated 2007, Louis Vuitton Malletier S.A. v. Haute Diggity Dog, LLC, case number 507 F.3d 252 [online]. [cit. 5. 5. 19]. Available at: https://www.law.berkeley.edu/ files/louisvuitton.pdf

Opinion of the Advocate General, delivered on 22 May 2014, in Case C-201/13. Deckmyn and Vrijheidsfonds v Vandersteen and Others, CJEU Info Curia Case-law: Available at: http://curia.europa.eu/juris/document/document.jsf?text=\&doc id $=152656$ \& pageIndex $=0 \&$ doclang $=E N \&$ mode $=1$ st $\&$ dir $=\& o c c=$ first $\&$ part $=1 \& c$ id $=9420552$

Registered Community Design number 000084223-0001. European Union Intellectual Property Office, EUIPO 1995-2019. [cit. 28. 8. 19]. Available at: https:// euipo.europa.eu/eSearch/\#details/designs/000084223-0001

Legal framework

Directive 2001/29/EC of the European Parliament and of the Council of 22 May 2001 on the harmonisation of certain aspects of copyright and related rights in the information society. Available at: https://eur-lex.europa.eu/legal-content/ EN/TXT/?qid=1566678022911\&uri=CELEX\%3A32001L0029

Regulation (EU) 2017/1001 of the European Parliament and of the Council of 14 June 2017 on the European Union Trademark. Available at: https://eur-lex.europa.eu/legal-content/EN/TXT/?qid=1567024746509\&uri=CELEX:32017R1001 


\section{Articles}

Šilhánková, Šárka (2019). Louis Vuitton As A Bully Brand. In: European Legal Studies and Research. International Conference of PhD Students in Law. Timisoara: Faculty of West University of Timisoara, 2019, pp. 372-377. ISSN 2066-6403.

The Fashion Law [online]: Chanel Settled its Lawsuit Over „Parody“ Tee, Diesl to Sue? (April 13, 2015), TFL LLC, 2012-2019 [cit. 28. 8. 19]. Available at: http:// www.thefashionlaw.com/home/chanel-settled-its-lawsuit-over-parody-tee-diesel-to-sue

The Fashion Law [online]: Hermes v. Thursday Friday (August 1. 2001), TFL LLC, 2012-2019 [cit. 28. 8. 19]. Available at: http://www.thefashionlaw.com/home/ hermes-v-thursday-friday

Picture source

Nadia Plesner website: Simple Living \& Darfurnica (undated); http://www. nadiaplesner.com/simple-living--darfurnica1 (accessed 28. 8. 2019) 


\author{
Mgr. Bc. Š́́rka Šilhánková, \\ Doktorantkinja, \\ Pravni fakultet, Masaryk Univerzitet, Brno, \\ Republika Češka
}

\title{
PARODIJA U PRAVU INTELEKTUALNE SVOJINE, U KONTEKSTU MODNOG PRAVA
}

\begin{abstract}
Rezime
Ovaj članak bavi se odnosom izmeđe parodije i prava intelektualne svojine. Autorka najpre predstavlja koncept i osnovne karakteristike parodije u evropskom pravu intelektualne svojine, sa posebnim osvrtom na upotrebu parodije u oblasti autorskog prava (copyright) i prava na zaštitu znaka/žiga (trademark). U tom kontekstu, detaljno je analizirana prva presuda Suda pravde Evropske unije (CJEU) koja se bavi ovom materijom u predmetu C-201/13 Deckmyn protiv Vandersteen. Pored razmatranja parodije u okviru autorskog prava i zaštite žigova, autorka predstavlja i nekoliko slučajeva iz oblasti modnog prava. S obzirom da sudska praksa Suda pravde EU ne sadrži presude iz oblasti modnog prava, autorka je istraživala sudsku praksu sudova u Sjedinjenim američkim državama. Većina slučajeva iz oblasti modnog prava obično se okončava sklapanjem strogo poverljivih sporazuma i vansudskom nagodbom. Manji broj slučajeva koji su bili predmet rasprave u nacionalnim sudskim postupcima ilustruju kako se parodija koristi u svetu mode.
\end{abstract}

Ključne reči: Evropsko pravo, parodija, pravo intelektualne svojine, modno pravo, sudska praksa, Louis Vuitton, Chanel, Hermes. 
